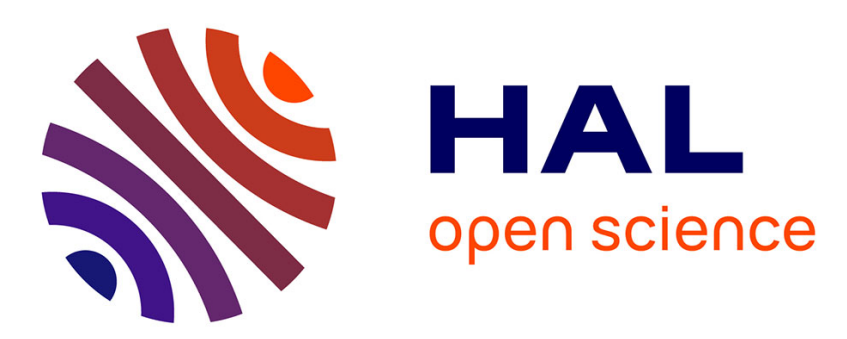

\title{
Fertilization and allelopathy modify Pinus halepensis saplings crown acclimation to shade
}

\author{
Y. Monnier, B. Vila, Anne Bousquet-Mélou, B. Prévosto, C. Fernandez
}

\section{To cite this version:}

Y. Monnier, B. Vila, Anne Bousquet-Mélou, B. Prévosto, C. Fernandez. Fertilization and allelopathy modify Pinus halepensis saplings crown acclimation to shade. Trees - Structure and Function, 2011, 25 (3), p. 497 - p. 507. hal-00637640

\section{HAL Id: hal-00637640 \\ https://hal.science/hal-00637640}

Submitted on 2 Nov 2011

HAL is a multi-disciplinary open access archive for the deposit and dissemination of scientific research documents, whether they are published or not. The documents may come from teaching and research institutions in France or abroad, or from public or private research centers.
L'archive ouverte pluridisciplinaire HAL, est destinée au dépôt et à la diffusion de documents scientifiques de niveau recherche, publiés ou non, émanant des établissements d'enseignement et de recherche français ou étrangers, des laboratoires publics ou privés. 


\section{Fertilization and allelopathy modify Pinus halepensis saplings crown}

\section{2 acclimation to shade}

3

4 Yogan Monnier ${ }^{1,2} \cdot$ Bruno Vila $^{1} \cdot$ Nicolas Montes $^{1} \cdot$ Anne Bousquet-Mélou ${ }^{1} \cdot$ Bernard Prévosto $^{2}$.

5 Catherine Fernandez ${ }^{1}$

6

7

(1) Institut Méditerranéen d'Ecologie et de Paléoécologie (IMEP, UMR CNRS 6116), Aix-Marseille Université, Centre St-Charles, 3 place Victor Hugo, 13331 Marseille cedex 03

(2) CEMAGREF, UR EMAX, 3275 Route de Cézanne CS 40061, 13182 Aix en Provence Cedex 5

corresponding author : Yogan Monnier

e-mail : yogan.monnier@yahoo.fr

tel : 04-88-57-69-74 Fax : 04-91-10-85-40

Abstract

Pinus halepensis Mill. is a Mediterranean pioneer forest species with shade intolerance features. The purpose of this study is to better understand how stand fertility and allelopathic properties of adult trees influence shade acclimation of saplings. Crown growth and morphological plasticity were studied under different light, fertilization, and allelopathic conditions in a nursery experiment. We tested whether shade-acclimation capacity increases with fertilization, and is affected by autotoxicity due to pine leachates. We examined stem diameter, and crown characteristics (length, width, shape and density) in a factorial experiment with two levels for each tested factor: light (full and $20 \%$ reduced light), fertilization (low and high rate of NPK fertilizer) and allelopathy (control and allelopathic leachates uptake). In our study, shading induced a significantly higher crown length, width and surface. Fertilization strongly increased crown length and vertical expended crown shape (the ratio crown length/crown width). Leachates uptake reduced crown length and density, highlighting an autotoxicity phenomenon. We concluded that $P$. halepensis saplings presented a shade avoiding syndrome and that the crown shade-acclimation response increased with fertilization but was severely compromised by autotoxicity. We finally discuss the role of fertilization and allelopathy in early $P$. halepensis acclimation ability. 
Vila B., Montes N., Bousquet-Melou A., Prevosto B. and Fernandez C. (2011) Fertilization and allelopathy modify Pinus halepensis saplings crown acclimation to shade, Trees-Structure and Function, 25, 3, 497-507. author-produced version of the final draft post-refeering the original publication is available at http://www.springerlink.com/content/g25g004p778x3463/ - doi:10.1007/s00468-010-0525-7

\section{Introduction}

Acclimation to shade is achieved by a remarkable variability in many structural features of plants including biomass allocation, physiological and morphological changes from leaf to whole plant scale (Delagrange et al. 2004; Givnish 1988; Kennedy et al. 2007; Messier and Nikinmaa 2000; Portsmuth and Niinemets 2007; Wang et al. 2006). At crown-level, several morphological changes are involved in the structural acclimation to the prevailing light environment. Plants exposed to high irradiance are frequently subjected to photoinhibition particularly under adverse conditions (Long et al. 1994) as in arid or Mediterranean-type environments. In this situation, plants exhibit a strategy based on the avoidance of excessive irradiance by structural features that reduce the leaf area directly exposed to the sun (Pearcy et al. 2005; Valladares and Pearcy 1998). This plastic response leads to foliage aggregation, highly branching and "bushy" growth form (Ali and Kikuzawa 2005; Shukla and Ramakrishnan 1986). By contrast, when plants grow in dense stands, decreased light availability leads plants to follow two principal strategies: shade tolerance and shade avoidance (Grime 1979; Henry and Aarssen 1997). "Shade-avoidance" means that a plant grown under low irradiance may maximize future light interception by a strong vertical growth (King 1990). This phenomenon involves a highly plastic response with accelerated extension growth, strong elongation of internode and petiole, and a strengthened apical dominance among other processes (Grime 1979; Smith and Whitelam 1997). All these morphological adjustments correspond to the concept of 'foraging for light' (Ballare et al. 1997), and result from modification of light quality strongly related to decrease of light quantity (Pecot et al. 2005). The proximity of neighbouring plants is detected by both biogenic volatile organic compounds and light receptors (sensing red and far-red light ratio and blue light), then shade avoidance responses occurre with the involvement of phytohormones (Franklin 2008; Kegge and Pierik 2010; Pierik et al. 2004; Stamm and Kumar 2010).

The "shade avoiders" are commonly ruderal herbs and pioneer tree species present in early to intermediate stage of succession, where the probability of encountering high irradiance with vertical growth is still reasonably high (Henry and Aarssen 1997; Smith 1982). Hence, emerging seedlings of early successional species show a high their neighbours and colonize canopy gaps (Gilbert et al. 2001). 
Vila B., Montes N., Bousquet-Melou A., Prevosto B. and Fernandez C. (2011) Fertilization and allelopathy modify Pinus halepensis saplings crown acclimation to shade, Trees-Structure and Function, 25, 3, 497-507. author-produced version of the final draft post-refeering the original publication is available at http://www.springerlink.com/content/g25g004p778x3463/ - doi:10.1007/s00468-010-0525-7

In this study we focus on a Mediterranean pioneer forest species, Pinus halepensis Mill. with intolerant-shade features (Puértolas et al. 2009; Zavala et al. 2000) allowing high growth rate under high light conditions. $P$. halepensis naturally regenerates within disturbed and relative open habitats, such as forest clearings, burned areas and abandoned agricultural lands (Buhk et al. 2006). In developing forests, $P$. halepensis predominates as an early recruit in secondary vegetation succession leading to monospecific dense stands where natural regeneration is absent or difficult (Prévosto and Ripert 2008). Causes of regeneration failure in these fire-free stands have been much less widely studied than post-fire regeneration. Light plays an important role in recruitment and growth beneath tree canopy for shade intolerant species like P. Halepensis (Zavala et al. 2000). However, $P$. halepensis growth responses to light availability during regeneration are still not well-defined. While Thanos (2000) reports a positive influence of light on germination, some authors observe that light availability does not have any effect on either germination (Broncano et al. 1998) or early seedling development measured a few days after germination (Fernandez et al. 2008). Broncano et al. (1998) noted similar growth rates (growth was evaluated through a volume index) under shaded (10\% full sunlight) compared to unshaded conditions on 8-month old $P$. halepensis saplings, while saplings reacted to shading by increasing elongation (stem height per stem basal diameter). In order to clarify the effects of irradiance on early pine aerial development, we analyzed the response of some crown structural parameters to shade.

In Mediterranean environments, in addition to water availability, soil nutrient content is also a frequent limiting factor for plant development (Sardans et al. 2005) including P. halepensis (Sardans et al. 2004). Soil nutrient availability can directly influence growth and biomass allocation, altering structural development of aerial parts of the plant (Ingestad and Agren 1991). More precisely, nutrient uptake strongly affects shoot length growth and foliar area production (Niinemets et al. 2002), changing acclimation capacity to shade (Coomes and Grubb 2000; Kobe 2006). In understory conditions soil nutrients were shown to exert a lower influence on growth, emphasizing the importance of considering light acclimation combined with nutrient effects (Broncano et al. 1998; Kobe 2006; Kranabetter and Simard 2008; Portsmuth 2006).

More recently, allelopathy was found to be implicated in renewal of forest stands (Mallik 2008). P. halepensis is known to release allelopathic compounds (Fernandez et al. 2006) with autotoxic effects affecting its own seedlings' initial growth (Fernandez et al. 2008). Autotoxicity may have important ecological implications such as the reduction of overcrowding and intraspecific competition for light water and nutrients (Singh et al. 1999). In our case, autotoxicity processes may be consistent with the pioneer and fast-expensive strategy of $P$. halepensis, avoiding long-term establishment at the same place and favouring an escape-strategy. Hence 
ila B., Montes N., Bousquet-Melou A., Prevosto B. and Fernandez C. (2011) Fertilization and allelopathy modify Pinus halepensis saplings crown acclimation to shade, Trees-Structure and Function, 25, 3, 497-507. author-produced version of the final draft post-refeering the original publication is available at http://www.springerlink.com/content/g25g004p778x3463/ - doi:10.1007/s00468-010-0525-7

allelopathic compounds (mainly phenolic acids) could influence aerial development of $P$. halepensis and impact light acclimation of saplings beneath the forest canopy. The allelopathic compounds interfere with seedling growth by causing plant growth inhibition, and nitrogen (N) immobilization (Inderjit et al. 2004; Inderjit 2006; Northup et al. 1995). Moreover, allelochemicals can affect development of roots tissue (Schenk 2006), leading to a decrease in nutrient uptake by the plant (Inderjit and Duke 2003; Yamasaki et al. 1998). P. halepensis leachates may therefore directly interfere with seedling acclimation capacity through the release of organic compounds and indirectly through soil nitrogen immobilization and/or decreasing uptake rates.

The objectives of this study were to better understand how stands fertility and allelopathic properties of adult trees influence shade acclimation of regenerating subjects. Both morphological and growth parameters (i.e., stem diameter, crown dimensions, crown shape, and foliar density) were studied under different light, fertilization, and allelopathic conditions in a nursery experiment. We tested two hypotheses: (1) does shade-acclimation capacities increase with fertilization and (2) does leachates of $P$. halepensis have a negative impact on shade acclimation of $P$. halepensis saplings, due to allelopathic properties?

\section{Materials and methods}

\section{Experimental design and treatment application}

The experiment was conducted in the administrative plant nursery of "Les Milles" (Departmental Directorate of Agriculture and Forestry of the Bouches-du-Rhône), in Aix-en-Provence, Southern France. The seeds were harvested in a Mediterranean pinewood, in the Luberon Massif. In May 2006, the experiment was established with 1-year-old nursery-grown $P$. halepensis seedlings of uniform size germinated and grown on an irrigated and fertilized artificial soil. Seedlings were transplanted one per pot, in 101 plastic pots filled with a draining substrate made of $25 \%$ calcareous sand, 25\% siliceous sand, and 50\% mineral soil from Provence Granulat quarry. This substrate was chosen in order to prevent allelopathic features of an organic substrate. The seedlings were grown outdoors during one year and regularly drip irrigated to prevent water stress. The factorial experimental design included three factors: (i) light availability, (ii) nutrient availability and (iii) presence of 
Fila B., Montes N , Bousquet-Melou A, Prevosto B, and Fernandez C. (2011) Fertilization and allelopathy modify Pinus halepensis saplings crown acclimation to shade, Trees-Structure and Function, 25, 3, 497-507. author-produced version of the final draft post-refeering the original publication is available at http://www.springerlink.com/content/g25g004p778x3463/ - doi:10.1007/s00468-010-0525-7

113

114

115

116

117

118

119

120

121

122

123

124

125

126

127

128

129

130

131

132

133

134

135

136

137

138

139

allelopathic compounds. For light availability, half of the pots were in full sunlight (high light, L+), and the other half under a shade cloth (EMIS france, ref. 1077) so as to reproduce light conditions under a dense pine wood canopy (Broncano et al. 1998; Maestre and Cortina 2004). Shade cloth was placed $2.5 \mathrm{~m}$ above ground to cover the entire plot area, and four additional net pieces on all plots orientations were placed vertically. Shade cloth transmittance, R:FR ratio and blue light describe the light conditions under the shading treatment. Transmittance and light quality, both under the shade and in the sun, were measured with a spectrometer (SpectrcoVio C5210C5220, Lab. Junior kit-SV2100, Korea Materials \& Analysis Corp. K-MAC). We measured the shade cloth light transmittance of total light spectra, defined as the ratio of photon flux density (PFD) beneath the shade cloth to the PFD in full sunlight. Transmittance below the shading nets was $23 \%$. Light quality was modified with shade cloth. Following Gasque and Garcia (2004) the red to far red ratio was measured at 660/730 nm respectively. R:FR was 1.54 for full light treatment (HL) and 1.11 for low light treatment (LL) similarly to values observed under Pinus halepensis cover (Gasque and García-Fayos 2004). Following Aphalo and Lehto (1997) photon flux density of blue light was measured at $450 \mathrm{~nm}$. Photon flux density of blue light under the shade cloth was $22 \%$ of the one measured under full light conditions. With regard to fertilization, two rates of fertilizer were supplied once by week with irrigation; the first composed of $75 \mathrm{mg} \mathrm{N}, 8.2 \mathrm{mg} \mathrm{P}$ and $20.74 \mathrm{mg} \mathrm{K}$ (low fertilization, F-) and the second five times higher (high fertilization $\mathrm{F}+$ ). Such process and fertilization rates are already used in greenhouse experiment with Aleppo pine saplings (Diaz et al. 2010). Finally, the allelopathic factor was tested through the use of leachates (Fernandez et al. 2008). Monthly, $25 \mathrm{~kg}$ of $P$. halepensis needles were harvested in a P. halepensis forest (circa 20 years old pine) near Aix-en-Provence, on the Arbois plateau. Needles were macerated in 2501 of water during 48 hours, in dark conditions (Yu et al. 2003) in order to obtain leachates at $10 \%$ fresh weight, corresponding at $5 \%$ dry weight (Fernandez et al. 2006). In this way, 0.51 of leachates was brought to half the pots (A+), while water was brought to the other half (A-).

Each treatment results from the combination of the two levels of the three factors (L, F, A). The resulting 8 treatments each contained 20 pots (=replicates) except the treatments with the lowest level of fertilizer with only 10 plants leading to a total of 120 pots for the whole experiment. Treatments were arranged in blocks, four under the shade cloth and four in full light, in $50 \mathrm{~m}^{2}$. Stem diameter, crown dimensions, crown shape and foliar density were used as response variables to analyse growth and morphological plasticity. 
ila B. Montes N , Bousquet-Melou A , Prevosto B and Fernandez C. (2011) Fertilization and allelopathy modify Pinus halepensis saplings crown acclimation to shade, Trees-Structure and Function, 25, 3, 497-507. author-produced version of the final draft post-refeering the original publication is available at http://www.springerlink.com/content/g25g004p778x3463/ - doi:10.1007/s00468-010-0525-7

\section{Growth measurements and crown descriptors}

143 Plasticity and crown morphological parameters were estimated on two-years old P. halepensis saplings using an 144 original and non-destructive method based on digital image analysis, previously tested on P. halepensis by 145 Montès et al. (2004).

146 The sampling procedure consisted in taking photographs of each individual, in March 2007, two years after the 147 beginning of the experiment. Because of a possible axial asymmetry of saplings, two pictures were taken from 148 orthogonal viewpoints, using a 3 megapixel digital camera. Using an image analysis software (Adobe ${ }^{\circledR}$ 149 Photoshop ${ }^{\circledR}$ CS2), photographs were then converted in three luminance levels (black for the surface area of the 150 sapling, grey for the outline and white for background of the image). For each sapling, the mean of the two 151 orthogonal views provide d a basis for deducing, from the number of pixels of each category, crown length (CL), 152 crown width (CW), surface area of the crown (CS) and crown outline (CO) (Fig. 1). Total height was not 153 considered as this dimension was very close to crown length due to branch insertion starting almost at stem base 154 for all the saplings. These parameters combined with stem diameter measurements (February 2007) were used to 155 make morphological and architectural trait descriptors: elongation (CL/D), crown shape (CL/CW), and crown 156 density $\left(\mathrm{CS} / \mathrm{CO}^{2}\right)$ which is an isometric indicator of crown openness. These plant parameters were compared for each treatment.

\section{Statistical analysis}

Multi-way ANOVA was used to analyze stem diameter, crown length, crown width, elongation, crown shape, crown surface and crown density as dependent variables, with light, fertilization and allelopathy levels, as the main factors. In case of significant interactions, one-way ANOVA was used to test differences. Afterwards, a Tukey test $(\mathrm{P}<0.05)$ was used to test differences between mean values of treatments. Normality and homoscedasticity were tested by Shapiro-Wilks' and Bartlett's tests, respectively. Due to violation of ANOVA assumptions for treatment at low fertilization level with no leachates uptake, the effect of the light factor on sapling growth variables was determined after a Kruskall-Wallis test. Allometric relationships between crown length, crown surface and crown density were determined through regressions. Changes in allocation pattern between treatments were assessed by comparison of the slopes and intercepts of regression lines using ANOVA. 
ila B. Montes N., Bousquet-Melou A., Prevosto B. and Fernandez C. (2011) Fertilization and allelopathy modify Pinus halepensis saplings crown acclimation to shade, Trees-Structure and Function, 25, 3, 497-507. author-produced version of the final draft post-refeering

the original publication is available at http://www.springerlink.com/content/g25g004p778x3463/ - doi:10.1007/s00468-010-0525-7

\section{Results}

All morphological parameters were significantly influenced by light, in interaction with fertilization and macerates (ANOVA, $\mathrm{P}<0.0001$; Table 1).

177 Crown length, elongation, crown width, vertical expended crown shape, and crown surface increased under low

178 light (L-) conditions (P < 0.001) (Fig. 2). Conversely, stem diameter and crown density decreased under low 179 light conditions but the difference was only significant for crown density $(\mathrm{P}=0.059$ for stem diameter). Under 180 high light (L+) and low light (L-) conditions crown surface increased with crown length with a strongly significant dependence $\left(\mathrm{P}<0.005 ; \mathrm{R}^{2}=0.29\right.$ and $\mathrm{P}=0.001 ; \mathrm{R}^{2}=0.80$ respectively; Fig. 3$)$. The level of irradiance did not influence the relationship between crown surface and crown length (differences between regression slopes, $\mathrm{P}=0.139)$. Crown density was significantly higher in $\mathrm{L}+$ than in $\mathrm{L}-(\mathrm{P}<0.001)$.

Fertilization effects in interaction with light (without allelopathy).

In treatments without allelopathy, there were significant interactions between light and fertilization effects on crown length, elongation, crown shape, crown surface $(\mathrm{P}<0.001)$. In $\mathrm{L}+$ conditions, no differences between the two fertilization levels for all parameters were noted whereas under L- conditions, higher fertilization led to higher values $(\mathrm{P}<0.001$, Tukey test) (Fig. 4). In contrast, crown density and width were never significantly affected by fertilization level $(\mathrm{P}>0.05)$. With regard to interaction, the increase observed for crown length, elongation, shape surface and width under shading conditions was much greater when the level of fertilization was high. High level of fertilization thus enables pines to have a more pronounced growth effect in low light and hence be more plastic. 
Vila B. Montes N. Bousquet-Melou A., Prevosto B. and Fernandez C. (2011) Fertilization and allelopathy modify Pinus halepensis saplings crown acclimation to shade, Trees-Structure and Function, 25, 3, 497-507. author-produced version of the final draft post-refeering the original publication is available at http://www.springerlink.com/content/g25g004p778x3463/ - doi:10.1007/s00468-010-0525-7

195

196

197

198

199

200

201

202

203

There were significant interactions between leachates and fertilization effects on crown length, crown surface and crown density $(\mathrm{P}<0.001)$. The increase of crown length, elongation shape surface and density due to high fertilisation was totally cancelled when allelopathic compounds were present (Fig. 5). For the lowest fertilization level, growth is low and leachates supply did not affect crown length and crown surface, but decreased crown density $(\mathrm{P}=0.007$, Tukey test; Fig. 5). With high rate of fertilization, growth is high and leachates did not affect crown density but decreased crown length, crown surface, and vertical expended crown shape $(\mathrm{P}<0.001$, Tukey test). Our results showed negative effects of leachates on aerial development, except on crown width.

\section{Discussion}

\section{Morphological effects of shade acclimation}

Shade acclimation has first been studied with standard level of nutrients (F-) and without leachates (A-). In this treatment, all morphological parameters of $P$. halepensis were positively and significantly influenced by shade except stem diameter, which decreased but not significantly. This negative impact of shade on stem diameter has been previously observed by Jose et al. (2003) on Pinus palustris Mill. seedlings, a shade intolerant pine species (Knapp et al. 2008). Moreover, Puertolas et al. (2009) reported similar trend on P. halepensis seedlings. In our study, the non-significant light influence on diameter is certainly due to the early age of saplings, the short-term length of the experiment and delayed response of stem increment to the treatment. Crown length (CL), crown elongation (CL/D), and crown shape (CL/CW) significantly increased in shade treatment. We found greater crown length in shade than under high light conditions which is consistent with previous studies where shade intolerant species showed similar or higher height growth in lower light availability during the first seasons (Chen and Klinka 1998; Groninger et al. 1996; Kennedy et al. 2007). Similar height variations have also been measured for P. halepensis (Puértolas et al. 2009) and for another early successional species, Pinus sylvestris L., which responded to shade with an increase in stem height (Dehlin et al. 2004). Enhancement of height growth in shade for light-demanding species could reflect a strategy of light-seeking by species adapted to the exploitation of high-resource environments (Walters et al. 1993). This growth strategy is common for shade-intolerant species to avoid shading by neighbouring vegetation (Ballare 1999; Grime 1979). In addition to the decrease of light quantity, neighbour plant canopy can also strongly modify light quality with a strong reduction of blue and 
Vila B., Montes N., Bousquet-Melou A., Prevosto B. and Fernandez C. (2011) Fertilization and allelopathy modify Pinus halepensis saplings crown acclimation to shade, Trees-Structure and Function, 25, 3, 497-507. author-produced version of the final draft post-refeering the original publication is available at http://www.springerlink.com/content/g25g004p778x3463/ - doi:10.1007/s00468-010-0525-7 red light absorbed by photosynthetic pigments and an increase of ethylene levels (Kegge and Pierik 2010; Pecot et al. 2005). The low R:FR, Blue light depression and a stimulated foliar ethylene emissions induce shade avoidance responses, such as enhanced stem elongation (Franklin 2008; Kegge and Pierik 2010; Pierik et al. 2004). This "shade avoidance" strategy involves maximizing light interception through architectural traits that contribute to a competitive advantage by strong vertical growth (Henry and Aarssen 1997; King 1990; Smith and Brewer 1994). As demonstrated by our results, the elongation (CL/CW) increase with light quantity decrease for P. halepensis., which has also been previously mentioned by Broncano et al. (1998) and for other species (Chen and Klinka 1998; Kennedy et al. 2007). This finding emphasizes the stronger shade avoidance response (Smith and Whitelam 1997). In addition to shade cloth effects on light quality, both density of plantation and proximity of neighbours may play a role by stimulating the shade avoidance signals and stem elongation (Anten et al. 2005; Pierik et al. 2004).

We also found crown width enhancement with decreasing light, which may be considered to be advantageous for foraging for light patches along horizontal gradients under forest canopies (Chen et al. 1996; Hutchings and Dekroon 1994). Under limited light conditions, a growth strategy that promotes lateral crown expansion might be favourable in enabling saplings to minimize self-shading and to improve light interception (Givnish 1988; Sterck et al. 2003). In our study, saplings have higher ratios of crown length to crown diameter in shade compared with higher light conditions, indicating that crowns shape were proportionally more vertically expanded in shade than in higher light. Such results differ from the positive relationship between this ratio and light availability generally observed in many studies for light-demanding tree species (Beaudet and Messier 1998; Chen et al. 1996; Klinka et al. 1992). These differences can be imputed to the strong interactions between light intensity and tree height, this last factor being in our case a strong determinant of architectural responses variability. Although shade avoiding syndrome increases both crown length and crown diameter, the former increases more than the latter, therefore saplings showed a more vertical expanded crown shape in shade. The crown surface increased while crown density decreased in shade only indicating a higher crown openness under shade conditions. Under L+ conditions, crown density was higher, indicating a higher proportion of hidden biomass within the crown, while in low light, most of the branching becomes apparent which enhances, with the same biomass allocation, photosynthetic capabilities. Results of crown surface and density analyses showed that high irradiance leads seedlings of shade-intolerant species to adopt a 'bushy' form whereas under shade conditions the crowns are more slender and vertically extended to prevent self-shading (Henry and Aarssen 1997; Henry and Aarssen 2001; King 1990; Shukla and Ramakrishnan 1986; Steingraeber et al. 1979). 
a B Montes N , Bousquet-Melou A, Prevosto B. and Fernandez C. (2011) Fertilization and allelopathy modify Pinus halepensis saplings crown acclimation to shade, Trees-Structure and Function, 25, 3, 497-507. author-produced version of the final draft post-refeering the original publication is available at http://www.springerlink.com/content/g25g004p778x3463/ - doi:10.1007/s00468-010-0525-7

\section{Fertilization effects on light acclimation}

Fertilization has frequently been described as a factor that can change allocation and aerial development in interaction with light availability (Coomes and Grubb 2000; Grubb et al. 1996; Kobe 2006; Portsmuth and Niinemets 2007). It has been suggested that light-dependent growth and plasticity depend on nutrient availability (Burton and Bazzaz 1995; Lortie and Aarssen 1996; Portsmuth and Niinemets 2007). In our study, for several parameters involved in crown shade acclimation, fertilization effect differed largely in light and shade conditions. In L+, nutrient uptake had no effect on morphological parameters, in line with the results of Portsmuth and Niinemets (2007) on others shade-intolerant species (given nevertheless that they reported results on growth rate and not morphological parameters). Conversely, under low light conditions, our results showed that architectural parameters (except crown width and crown density) were strongly influenced by nutrients in contrast with general conclusions of Portsmuth and Niinemets (2007) based on works of Poorter and Nagel (2000). The latter have found that nutrient requirement is higher and growth is more responsive to nutrients at higher irradiance. To explain these results, Poorter and Nagel (2000) noted that higher irradiance implies a higher rate of photosynthesis per unit leaf mass, but also a higher rate of water uptake due to increased transpiration and a higher nutrient uptake because growth is stimulated. They showed, in accordance with the functional equilibrium model, that biomass was more preferentially allocated to plant parts related to limited resource. Hence, the fraction of biomass allocated to roots increased proportionally with irradiance at nonlimited nutrient level. In the same way, under L- conditions, nutrient increase improved primarily the fraction of biomass invested in the stems, and changed the morphological development of aboveground parts of the plant as detected in this study for crown descriptors. In our study, the increase observed for crown length, elongation, shape surface and width in shading conditions versus high light conditions was much greater when nutrient availability was high. High level of fertilization thus allows pines to have a more pronounced growth effect in low light and therefore be more plastic. Comparable variations in aerial components of pioneer species have been observed in P. sylvestris (de la Rosa et al. 1984). Increased aerial growth response to shade under more fertile conditions implies a competitive advantage over neighbouring plants through pre-emptive capture of light resources, especially under high-fertilization conditions, where competition from other seedlings is likely to be intense. 
Vila B. Montes N., Bousquet-Melou A., Prevosto B. and Fernandez C. (2011) Fertilization and allelopathy modify Pinus halepensis saplings crown acclimation to shade, Trees-Structure and Function, 25, 3, 497-507. author-produced version of the final draft post-refeering the original publication is available at http://www.springerlink.com/content/g25g004p778x3463/ - doi:10.1007/s00468-010-0525-7

Major allelopathic effects on crown development were conspicuous under shade conditions in interaction with nutrient availability. At lower rate of fertilization, leachates supply only reduced crown density whereas in high fertilization, leachates supply reduced crown length, surface and elongation ratio (H/D). Such inhibition of crown development may be caused by phenolic acids by (1) nitrogen immobilization (Inderjit et al. 2004; Inderjit 2006; Northup et al. 1995), (2) root and vegetative tissue degradation by cytotoxicity, (Schenk 2006) and/or a complex process of interactions with microorganisms and mycorrhizae. Some authors reported that growth inhibitor effects caused by leachates supply were eliminated by addition of fertilizers (Einhellig 1999; Inderjit 2006). Similarly to Inderjit et al. (2004), we noted that the main phytotoxic effects occurred at high level of fertilization. Nitrogen addition could increase microbial populations that could influence qualitative and quantitative availability of phenolic compounds (Inderjit et al. 2004). These phenolic compounds can form recalcitrant complexes with proteins and modify nutrient availability (Hättenschwiler and Vitousek 2000) which could lead to a detrimental influence on sapling growth. It should be noted that many phenolic compounds are present in P. halepensis leachates (Fernandez et al. 2009). Interactions with ectomycorrhizae may also explain the absence of effect of leachates supply at low soil fertility. While a high fertilization had been described to be nefast for P. halepensis ectomycorrhizae, at low fertilization level ectomycorrhizae can develop (Diaz et al. 2010) and may detoxify phenolic compounds like described on different species (Zeng and Mallik 2006). To our knowledge, no study looked at plant crown architectural response to allelopathy. Crown length inhibition observed in this study under F+ conditions led to a decrease of elongation and vertical expanded crown shape, modifying strongly crown morphology and seedlings' acclimation ability to shade, confirmed by crown surface decrease. In fact, plastic adjustments of crown morphology due to higher fertilization are cancelled with leachates supply. Hence, allelopathy, and more precisely autotoxicity, severely affected P. halepensis saplings' acclimation to low irradiance during the first years. Autotoxicity in P. halepensis has already been noted in germination and initial growth (10-days-old seedlings) under laboratory conditions (Fernandez et al. 2008). With our experiment, we confirmed the autotoxic effects of $P$. halepensis needles leachates on sapling development. This study highlights the negative effects of allelopathy on $P$. halepensis saplings acclimation to shade and complex interactions with fertility conditions. By affecting height growth in non-limited soil fertility conditions, autotoxicity could have an impact on saplings acclimation to limited light beneath the canopy, and potentially on regeneration of $P$. halepensis stands. 
nnier Y., Vila B., Montes N., Bousquet-Melou A., Prevosto B. and Fernandez C. (2011) Fertilization and allelopathy modify Pinus halepensis saplings crown acclimation to shade, Trees-Structure and Function, 25, 3, 497-507. author-produced version of the final draft post-refeering

the original publication is available at http://www.springerlink.com/content/g25g004p778x3463/ - doi:10.1007/s00468-010-0525-7

311 Acknowledgments This study was funded by the CNRS within the framework of the Zone Atelier "Arrière-

312 pays Méditerranéen". We thank the staff of the administrative plant nursery of Les Milles (Departmental

313 Directorate of Agriculture and Forestry of the Bouches-du-Rhône, France), particularly Patrice Brahic for his

314 useful comments and all the staff for technical assistance. We would also like to thank Michal Paul for

315 proofreading the english, Nicolas Faivre and Chrisinte Scoffoni for their comments that improve the manuscript,

316 and Sylvie Dupouyet, Stéphane Greff, Caroline Lecareux, Céline Pernin and the DFCV team who assisted us

317 with collection of needles and for leachates confection and watering.

318 
Vila B. Montes N., Bousquet-Melou A., Prevosto B. and Fernandez C. (2011) Fertilization and allelopathy

modify Pinus halepensis saplings crown acclimation to shade, Trees-Structure and Function, 25, 3, 497-507.

author-produced version of the final draft post-refeering

the original publication is available at http://www.springerlink.com/content/g25g004p778x3463/ - doi:10.1007/s00468-010-0525-7

\section{References}

320

Ali M, Kikuzawa K (2005) Plasticity in leaf-area density within the crown of Aucuba japonica growing under different light levels. J Plant Res 118:307-316

Anten NPR, Casado-Garcia R, Nagashima H (2005) Effects of mechanical stress and plant density on mechanical characteristics, growth, and lifetime reproduction of tobacco plants. Am Nat 166 (6):650-660

Aphalo PJ, Lehto T (1997) Effects of light quality on growth and $n$ accumulation in birch seedlings. Tree Physiol $17: 125-132$

Ballare CL (1999) Keeping up with the neighbours: phytochrome sensing and other signalling mechanisms. Trends Plant Sci 4:97-102

Ballare CL, Scopel AL, Sanchez RA (1997) Foraging for light: photosensory ecology and agricultural implications. Plant, Cell Environ 20:820-825

Beaudet M, Messier C (1998) Growth and morphological responses of yellow birch, sugar maple, and beech seedlings growing under a natural light gradient. Can J For Res 28:1007-1015

Broncano MJ, Riba M, Retana J (1998) Seed germination and seedling performance of two Mediterranean tree species, holm oak (Quercus ilex L.) and Aleppo pine (P. halepensis Mill.) : a multifactor experimental

Buhk C, Götzenberger L, Wesche K, Gómez PS, Hensen I (2006) Post-fire regeneration in a Mediterranean pine approach. Plant Ecol 138:17-26 forest with historically low fire frequency. Acta Oecol 30:288-298

Burton PJ, Bazzaz FA (1995) Ecophysiological responses of tree seedlings invading different patches of old-field vegetation. J Ecol 83:99-112

Chen HYH, Klinka K (1998) Survival, growth, and allometry of planted Larix occidentalis seedlings in relation to 
Vila B., Montes N., Bousquet-Melou A., Prevosto B. and Fernandez C. (2011) Fertilization and allelopathy

modify Pinus halepensis saplings crown acclimation to shade, Trees-Structure and Function, 25, 3, 497-507.

author-produced version of the final draft post-refeering

the original publication is available at http://www.springerlink.com/content/g25g004p778x3463/ - doi:10.1007/s00468-010-0525-7

Chen HYH, Klinka K, Kayahara GJ (1996) Effects of light on growth, crown architecture, and specific leaf area for naturally established Pinus contorta var latifolia and Pseudotsuga menziesii var glauca saplings. Can J For Res 26:1149-1157

Coomes DA, Grubb PJ (2000) Impacts of root competition in forests and woodlands: a theoretical framework and review of experiments. Ecol Monogr 70:171-207

de la Rosa TM, Aphalo PJ, Lehto T (1998) Effects of far-red light on the growth, mycorrhizas and mineral nutrition of Scots pine seedlings. Plant Soil 201:17-25

Dehlin H, Nilsson MC, Wardle DA, Shevtsova A (2004) Effects of shading and humus fertility on growth, competition, and ectomycorrhizal colonization of boreal forest tree seedlings. Can J For Res 34:25732586

Delagrange S, Messier C, Lechowicz MJ, Dizengremel P (2004) Physiological, morphological and allocational plasticity in understory deciduous trees: importance of plant size and light availability. Tree Physiol 24:775-784

Diaz G, Carrillo C, Honrubia M (2010) Mycorrhization, growth and nutrition of Pinus halepensis seedlings fertilized with different doses and sources of nitrogen. Ann For Sci 67:405

Einhellig FA (1999) An integrated view of phytochemicals amid multiple stresses. In: Inderjit, Dakshini KMM, Foy CL (eds) Principles and practices in plant ecology: phytochemicals interactions. CRC Press, Boca Raton, pp 479-494

Fernandez C, Lelong B, vila B, Mévy J-P, Robles C, Greff S, Dupouyet S, Bousquet-Mélou A (2006) Potential allelopathic effect of $P$. halepensis in the secondary succession: an experimental approach. Chemoecology 16:97-105

Fernandez C, Monnier Y, Ormeno E, Baldy V, Greff S, Pasqualini V, Mevy JP, Bousquet-Melou A (2009) Variations in Allelochemical Composition of Leachates of Different Organs and Maturity Stages of $P$. halepensis. J Chem Ecol 35:970-979 
Vila B., Montes N , Bousquet-Melou A, Prevosto B. and Fernandez C. (2011) Fertilization and allelopathy modify Pinus halepensis saplings crown acclimation to shade, Trees-Structure and Function, 25, 3, 497-507. author-produced version of the final draft post-refeering

the original publication is available at http://www.springerlink.com/content/g25g004p778x3463/ - doi:10.1007/s00468-010-0525-7

Fernandez C, Voiriot S, Mévy J-P, Vila B, Ormeño E, Dupouyet S, Bousquet-Mélou A (2008) Regeneration failure of $P$. halepensis Mill.: The role of autotoxicity and some abiotic environmental parameters. For Ecol Manag 255:2928-2936

Franklin KA (2008) Shade avoidance. New Phytol 179:930-944

Gasque M, García-Fayos P (2004) Interaction between Stipa tenacissima and P. halepensis: Consequences for reforestation and the dynamics of grass steppes in semi-arid mediterranean areas. For Ecol Manag $189: 251-261$

Gilbert IR, Jarvis PG, Smith H (2001) Proximity signal and shade avoidance differences between early and late successional trees. Nature 411:792-795

Givnish TJ (1988) Adaptation to sun and shade: a whole-plant perspective. Aust J Plant Physiol 15:63-92

Grime JP (1979) Plant strategies and vegetation processes. John Wiley \& Sons Ltd, Chichester, New York

Groninger JW, Seiler JR, Peterson JA, Kreh RE (1996) Growth and photosynthetic responses of four Virginia Piedmont tree species to shade. Tree Physiol 16:773-778

Grubb PJ, Lee WG, Kollmann J, Wilson JB (1996) Interaction of irradiance and soil nutrient supply on growth of seedlings of ten European tall-shrub species and Fagus sylvatica. J Ecol 84:827-840

Hättenschwiler S, Vitousek PM (2000) The role of polyphenols in terrestrial ecosystem nutrient cycling. Trends Ecol Evol 15:238-243

Henry HAL, Aarssen LW (1997) On the relationship between shade solerance and shade avoidance strategies in woodland plants. Oikos 80:575-582

Henry HAL, Aarssen LW (2001) Inter- and intraspecific relationships between shade tolerance and shade avoidance in temperate trees. Oikos 93:477-487

Hutchings MJ, Dekroon H (1994) Foraging in plants: the role of morphological plasticity in resource acquisition. Adv Ecol Res 25:159-238 
Vila B. Montes N , Bousquet-Melou A., Prevosto B. and Fernandez C. (2011) Fertilization and allelopathy modify Pinus halepensis saplings crown acclimation to shade, Trees-Structure and Function, 25, 3, 497-507. author-produced version of the final draft post-refeering the original publication is available at http://www.springerlink.com/content/g25g004p778x3463/ - doi:10.1007/s00468-010-0525-7

Inderjit (2006) Experimental complexities in evaluating the allelopathic activities in laboratory bioassays: A case study. Soil Biol Biochem 38:256-262

Inderjit, Duke SO (2003) Ecophysiological aspects of allelopathy. Planta 217:529-539

Inderjit, Rawat DS, Foy CL (2004) Multifaceted approach to determine rice straw phytotoxicity. Can J Bot 82:168-176

Ingestad T, Agren GI (1991) The influence of plant nutrition on biomass allocation. Ecol Appl 1:168-174

Jose S, Merritt S, Ramsey CL (2003) Growth, nutrition, photosynthesis and transpiration responses of longleaf pine seedlings to light, water and nitrogen. For Ecol Manag 180:335-344

Kegge W, Pierik R (2010) Biogenic volatile organic compounds and plant competition. Trends Plant Sci 15:126132

Kennedy S, Black K, O'Reilly C, Ni Dhubhain A (2007) The impact of shade on morphology, growth and biomass allocation in Picea sitchensis, Larix x eurolepis and Thuja plicata. New For 33:139-153

King DA (1990) The adaptive significance of tree height. Am Nat 135:809-828

Klinka K, Wang Q, Kayahara GJ, Carter RE, Blackwell BA (1992) Light-growth response relationships in pacific silver fir (Abies amabilis) and sub-alpine fir (Abies lasiocarpa). Can J Bot 70:1919-1930

Knapp BO, Wang GG, Walker JL (2008) Relating the survival and growth of planted longleaf pine seedlings to microsite conditions altered by site preparation treatments. For Ecol Manag 255:3768-3777

Kobe R (2006) Sapling growth as a function of light and landscape-level variation in soil water and foliar nitrogen in northern Michigan. Oecologia 147:119-133

Kranabetter JM, Simard SW (2008) Inverse relationship between understory light and foliar nitrogen along productivity gradients of boreal forests. Can J For Res 38:2487-2496

Liu YH, Sen Zeng R, An M, Mallik AU, Luo SM (2008) Autotoxicity in agriculture and forestry. In: Zeng RS, Mallik AU, Luo SM (eds) Allelopathy in Sustainable Agriculture and Forestry. Springer, New York, pp 283-301 
ila B. Montes N , Bousquet-Melou A., Prevosto B. and Fernandez C. (2011) Fertilization and allelopathy

modify Pinus halepensis saplings crown acclimation to shade, Trees-Structure and Function, 25, 3, 497-507.

author-produced version of the final draft post-refeering

the original publication is available at http://www.springerlink.com/content/g25g004p778x3463/ - doi:10.1007/s00468-010-0525-7

Long SP, Humphries S, Falkowski PG (1994) Photoinhibition of photosynthesis in nature. Annu Rev Plant Physiol Plant Mol Biol 45:633-662

Lortie CJ, Aarssen LW (1996) The specialization hypothesis for phenotypic plasticity in plants. Int J Plant Sci 157:484-487

Maestre FT, Cortina J (2004) Are Pinus halepensis plantations useful as a restoration tool in semiarid Mediterranean areas? For Ecol Manag 198:303-317

Mallik AU (2008) Allelopathy in forested ecosystems. In: Zeng RS, Mallik AU, Luo SM (eds) Allelopathy in Sustainable Agriculture and Forestry. Springer, New York, pp 363-386

Messier C, Nikinmaa E (2000) Effects of light availability and sapling size on the growth, biomass allocation, and crown morphology of understory sugar maple, yellow birch, and beech. Ecoscience 7:345-356

Montès N, Ballini C, Bonin G, Faures J (2004) A comparative study of aboveground biomass of three Mediterranean species in a post-fire succession. Acta Oecol 25:1-6

Niinemets U, Cescatti A, Lukjanova A, Tobias M, Truus L (2002) Modification of light-acclimation of Pinus sylvestris shoot architecture by site fertility. Agric For Meteorol 111:121-140

Northup RR, Yu Z, Dahlgren RA, Vogt KA (1995) Polyphenol control of nitrogen release from pine litter. Nature $377: 227-229$

Pearcy RW, Muraoka H, Valladares F (2005) Crown architecture in sun and shade environments: assessing function and trade-offs with a three-dimensional simulation model. New Phytol 166:791-800

Pecot SD, Horsley SB, Battaglia MA, Mitchell RJ (2005) The influence of canopy, sky condition, and solar angle on light quality in a longleaf pine woodland. Can J For Res 35:1356-1366

Pierik R, Whitelam GC, Voesenek L, de Kroon H, Visser EJW (2004) Canopy studies on ethylene-insensitive tobacco identify ethylene as a novel element in blue light and plant-plant signalling. Plant J 38:310-319

Poorter $\mathrm{H}$, Nagel O (2000) The role of biomass allocation in the growth response of plants to different levels of light, CO2, nutrients and water: a quantitative review. Aust J Plant Physiol 27:1191-1191 
nier Y. Vila B. Montes N., Bousquet-Melou A., Prevosto B. and Fernandez C. (2011) Fertilization and allelopathy modify Pinus halepensis saplings crown acclimation to shade, Trees-Structure and Function, 25, 3, 497-507. author-produced version of the final draft post-refeering

the original publication is available at http://www.springerlink.com/content/g25g004p778x3463/ - doi:10.1007/s00468-010-0525-7

Portsmuth A, Niinemets U (2007) Structural and physiological plasticity in response to light and nutrients in five temperate deciduous woody species of contrasting shade tolerance. Funct Ecol 21:61-77

Portsmuth A, Niinemets Ü (2006) Interacting controls by light availability and nutrient supply on biomass allocation and growth of Betula pendula and B. pubescens seedlings. For Ecol Manag 227:122-134

Prévosto B, Ripert C (2008) Regeneration of $P$. halepensis stands after partial cutting in southern France: Impacts of different ground vegetation, soil and logging slash treatments. For Ecol Manag 256:20582064

Puértolas J, Benito L, Peñuelas J (2009) Effects of nursery shading on seedling quality and post-planting performance in two Mediterranean species with contrasting shade tolerance. New For 38:295-308

Sardans J, Roda F, Penuelas J (2004) Phosphorus limitation and competitive capacities of $P$. halepensis and Quercus ilex subsp rotundifolia on different soils. Plant Ecol 174:305-317

Sardans J, Rodà F, Peñuelas J (2005) Effects of water and a nutrient pulse supply on Rosmarinus officinalis growth, nutrient content and flowering in the field. Environ Exp Bot 53:1-11

Schenk HJ (2006) Root competition: beyond resource depletion. J Ecol 94:725-739

Shukla RP, Ramakrishnan PS (1986) Architecture and growth strategies of tropical trees in relation to successional status. J Ecol 74:33-46

Singh HP, Batish DR, Kohli RK (1999) Autotoxicity: Concept, organisms, and ecological significance. Crit Rev Plant Sci 18:757-772

Smith H (1982) Light quality, photoperception, and plant strategy. Annu Rev Plant Physiol Plant Mol Biol 33:481-518

Smith H, Whitelam GC (1997) The shade avoidance syndrome: multiple responses mediated by multiple phytochromes. Plant Cell Environ 20:840-844

Smith WK, Brewer CA (1994) The adaptive importance of shoot and crown architecture in conifer trees. Am Nat 143:528-532 
ila B., Montes N., Bousquet-Melou A., Prevosto B. and Fernandez C. (2011) Fertilization and allelopathy modify Pinus halepensis saplings crown acclimation to shade, Trees-Structure and Function, 25, 3, 497-507. author-produced version of the final draft post-refeering

the original publication is available at http://www.springerlink.com/content/g25g004p778x3463/ - doi:10.1007/s00468-010-0525-7

Stamm P, Kumar PP (2010) The phytohormone signal network regulating elongation growth during shade avoidance. Journal of Experimental Botany 61:2889-2903

Steingraeber DA, Kascht LJ, Franck DH (1979) Variation of shoot morphology and bifurcation ratio in sugar maple (Acer saccharum) saplings. Am J Bot 66:441-445

Sterck F, Martinéz-Ramos M, Dyer-Leal G, Rodríguez-Velazquez J, Poorter L (2003) The consequences of crown traits for the growth and survival of tree saplings in a Mexican lowland rainforest. Funct Ecol 17:194-200

Thanos CA (2000) Ecophysiology of seed germination in P. halepensis and P. brutia. In: G. Ne, L. T (eds) Ecology, Biogeography and Management of $P$. halepensis and $P$. Brutia Forest Ecosystems in the Mediterranean Basin. Backhuys Publishers, Leiden, pp 37-50

Valladares F, Pearcy RW (1998) The functional ecology of shoot architecture in sun and shade plants of Heteromeles arbutifolia M. Roem., a Californian chaparral shrub. Oecologia 114:1-10

Walters MB, Kruger EL, Reich PB (1993) Growth, biomass distribution and CO2 exchange of northern hardwood seedlings in high and low light: relationships with successional status and shade tolerance. Oecologia $94: 7-16$

Wang GG, Bauerle WL, Mudder BT (2006) Effects of light acclimation on the photosynthesis, growth, and biomass allocation in American chestnut (Castanea dentata) seedlings. For Ecol Manag 226:173-180

Yamasaki SH, Fyles JW, Egger KN, Titus BD (1998) The effect of Kalmia angustifolia on the growth, nutrition, and ectomycorrhizal symbiont community of black spruce. For Ecol Manag 105:197-207

Yu JQ, Ye SF, Zhang MF, Hu WH (2003) Effects of root exudates and aqueous root extracts of cucumber (Cucumis sativus) and allelochemicals, on photosynthesis and antioxidant enzymes in cucumber. Biochem Syst Ecol 31:129

Zavala MA, Espelta JM, Retana J (2000) Constraints and trade-offs in Mediterranean plant communities: The case of holm oak-Aleppo pine forests. Bot Rev 66:119-149

Zeng R, Mallik A (2006) Selected ectomycorrhizal fungi of black spruce (Picea mariana) can detoxify phenolic compounds of Kalmia angustifolia. J Chem Ecol 32:1473-1489 
Mnnier Y., Vila B., Montes N., Bousquet-Melou A., Prevosto B. and Fernandez C. (2011) Fertilization and allelopathy author-produced version of the final draft post-refeering

the original publication is available at http://www.springerlink.com/content/g25g004p778x3463/ - doi:10.1007/s00468-010-0525-7 
Vila B. Montes N , Bousquet-Melou A., Prevosto B. and Fernandez C. (2011) Fertilization and allelopathy

modify Pinus halepensis saplings crown acclimation to shade, Trees-Structure and Function, 25, 3, 497-507.

author-produced version of the final draft post-refeering

the original publication is available at http://www.springerlink.com/content/g25g004p778x3463/ - doi:10.1007/s00468-010-0525-7

Tables and Figures caption

488

489

Table 1 ANOVA results for stem diameter (D), crown length (CL), crown elongation (CL/D), crown shape

490

(CL/CW), crown width (CW), crown surface (CS) and crown density (CD) as a function of light (L), fertilization (F)

491

and allelopathy (A) and their interactions. Significant effects $(\alpha=0.05)$ are in bold

492

493

Fig 1 Schematic representation of a sapling, and the measured variables: stem diameter (D), crown length (CL),

494

crown width (CW), crown surface (CS), crown outline (CO)

495

496

Fig 2 Means and standard errors for crown length (CL), crown elongation (CL/D), crown width (CW), crown

497

shape (CL/CW), crown surface $(\mathrm{S})$ and crown density (CD) in high light $(\mathrm{L}+)$ and low light $(\mathrm{L}-)$ are presented only

498

for the low ferrtilization (F-) and without allelopathy (A-) . Contrasting letters refer to significant differences

499

(post hoc Tukey test $P<0.05$ )

500

501

Fig 3 Relationship between crown surface (CS) and crown length (CL) as a function of light level. The responses

of surface to height have been compared in high light ( $L+)$ and low light (L-) treatment

503

504 Fig 4 Interactions, means and standard errors for light and fertilization effects on crown length (CL), crown

505 elongation $(C L / D)$, crown width $(C W)$, crown shape $(C L / C W)$, crown surface $(S)$ and crown density $(C D)$ in

506 treatments without allelopathy (A-). Contrasting letters refer to significant differences (Tukey test $P<0.05$ ) 
nnier Y., Vila B., Montes N., Bousquet-Melou A., Prevosto B. and Fernandez C. (2011) Fertilization and allelopathy author-produced version of the final draft post-refeering

the original publication is available at http://www.springerlink.com/content/g25g004p778x3463/ - doi:10.1007/s00468-010-0525-7

508 Fig 5 Interactions, means and standard errors for allelopathic and fertilization effects on crown length (CL),

509 crown elongation $(C L / D)$, crown width $(C W)$, crown shape $(C L / C W)$, crown surface $(S)$ and crown density $(C D)$ in low light treatments (L-). Contrasting letters refer to significant differences (Tukey test $P<0.05$ ) 
ontes N., Bousquet-Melou A., Prevosto B. and Fernandez C. (2011) Fertilization and allelopathy

author-produced version of the final draft post-refeering

the original publication is available at http://www.springerlink.com/content/g25g004p778x3463/ - doi:10.1007/s00468-010-0525-7

\begin{tabular}{|c|c|c|c|c|c|c|c|c|c|c|c|c|c|c|}
\hline \multirow[b]{2}{*}{ Source } & \multicolumn{2}{|c|}{$\begin{array}{c}\text { Stem } \\
\text { diameter (D) }\end{array}$} & \multicolumn{2}{|c|}{$\begin{array}{c}\text { Crown length } \\
\text { (CL) }\end{array}$} & \multicolumn{2}{|c|}{$\begin{array}{l}\text { Crown width } \\
\text { (CW) }\end{array}$} & \multicolumn{2}{|c|}{$\begin{array}{c}\text { Elongation } \\
\text { (CL/D) }\end{array}$} & \multicolumn{2}{|c|}{$\begin{array}{c}\text { Crown } \\
\text { shape } \\
\text { (CL/CW) }\end{array}$} & \multicolumn{2}{|c|}{$\begin{array}{c}\text { Crown } \\
\text { surface (CS) }\end{array}$} & \multicolumn{2}{|c|}{$\begin{array}{c}\text { Crown } \\
\text { Density } \\
\left(\mathrm{CS} / \mathrm{CO}^{2}\right)\end{array}$} \\
\hline & $\mathrm{F}$ & $\mathrm{P}$ & $\mathrm{F}$ & $\mathrm{P}$ & $\mathrm{F}$ & $\mathrm{P}$ & $\mathrm{F}$ & $\mathrm{P}$ & $\mathrm{F}$ & $\mathrm{P}$ & $\mathrm{F}$ & $\mathrm{P}$ & $\mathrm{F}$ & $\mathrm{P}$ \\
\hline Light (L) & 10.00 & 0.002 & 148.98 & 0.000 & 104.36 & 0.000 & 178.82 & 0.000 & 13.25 & 0.000 & 106.81 & 0.000 & 233.84 & 0.000 \\
\hline Fertiliser $(F)$ & 0.71 & ns & 23.57 & 0.000 & 2.72 & ns & 14.22 & 0.001 & 36.33 & 0.000 & 0.56 & ns & 5.89 & 0.039 \\
\hline Allelopathy (A) & 9.96 & 0.002 & 2.36 & ns & 4.89 & 0.029 & 0.07 & ns & 0.41 & ns & 0.36 & ns & 8.58 & 0.008 \\
\hline \multicolumn{15}{|l|}{ Interactions } \\
\hline $\mathrm{LxF}$ & 0.57 & ns & 0.15 & ns & 10.79 & 0.001 & 0.01 & ns & 5.58 & 0.020 & 7.54 & 0.007 & 0.40 & ns \\
\hline LXA & 1.89 & ns & 22.16 & 0.000 & 2.81 & ns & 12.5 & 0.001 & 35.02 & 0.000 & 6.45 & 0.013 & 2.47 & ns \\
\hline FxA & 4.83 & 0.030 & 0.73 & ns & 1.91 & ns & 3.12 & ns & 1.07 & ns & 4.69 & 0.032 & 1.50 & ns \\
\hline LxFxA & 15.18 & 0.000 & 47.7 & 0.000 & 0.79 & ns & 18.01 & 0.000 & 35.13 & 0.000 & 18.71 & 0.000 & 12.17 & 0.006 \\
\hline
\end{tabular}

512

Table 1

513

514

515

516

517

518

519

520 
Monnier Y., Vila B., Montes N., Bousquet-Melou A., Prevosto B. and Fernandez C. (2011) Fertilization and allelopathy

author-produced version of the final draft post-refeering

the original publication is available at http://www.springerlink.com/content/g25g004p778x3463/ - doi:10.1007/s00468-010-0525-7

522

523

524

525

526

527

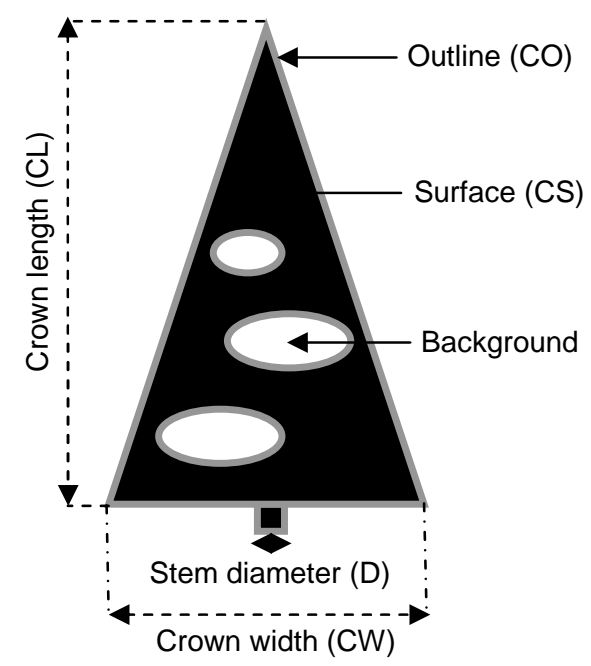

528

529

Fig. 1 
(2011) Fertilization and allelopathy

modify Pinus halepensis saplings crown acclimation to shade, Trees-Structure and Function, 25, 3, 497-507.

author-produced version of the final draft post-refeering

the original publication is available at http://www.springerlink.com/content/g25g004p778x3463/ - doi:10.1007/s00468-010-0525-7
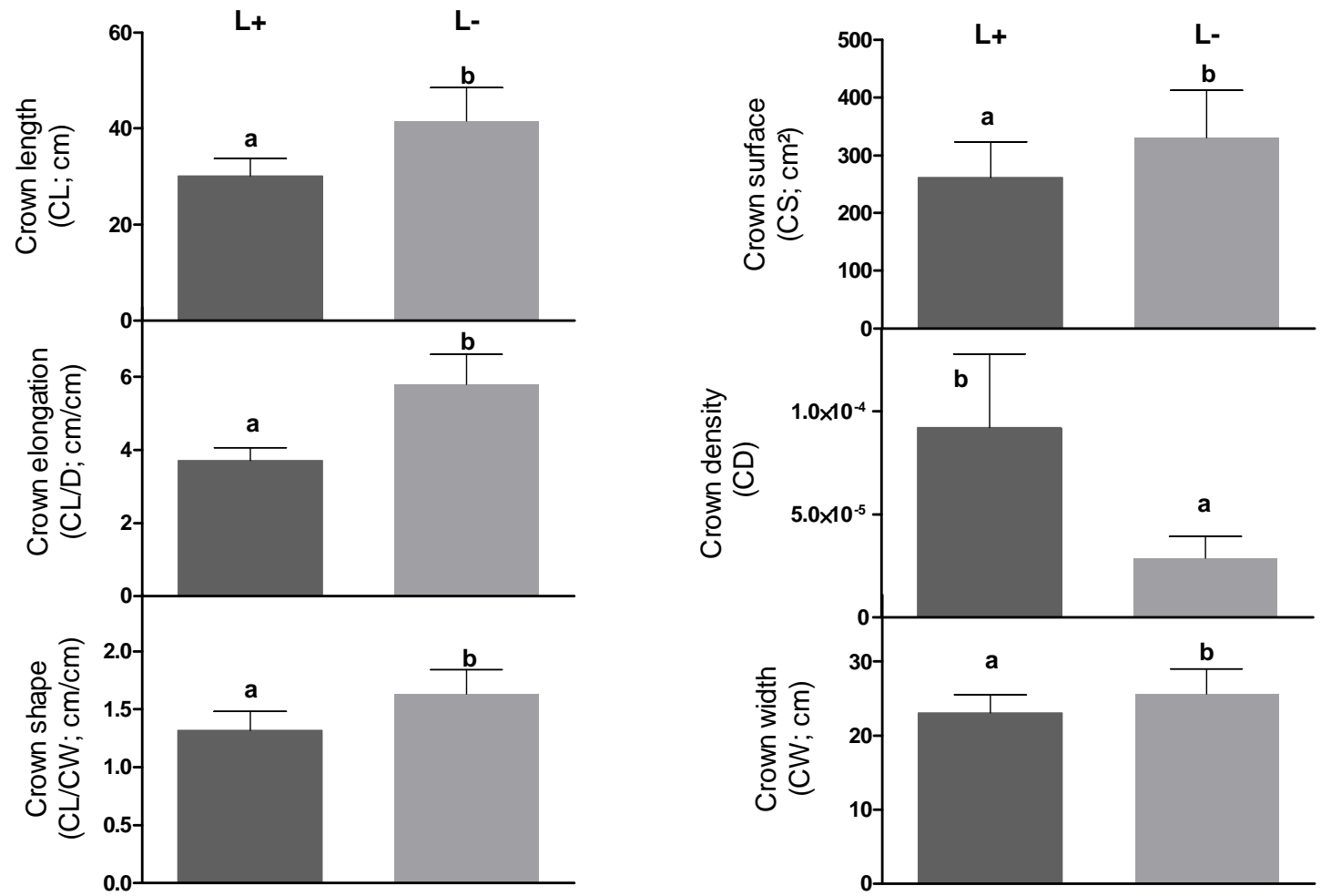

Fig. 2 
onnier Y., Vila B., Montes N., Bousquet-Melou A., Prevosto B. and Fernandez C. (2011) Fertilization and allelopathy

modify Pinus halepensis saplings crown acclimation to shade, Trees-Structure and Function, 25, 3, 497-507.

author-produced version of the final draft post-refeering

the original publication is available at http://www.springerlink.com/content/g25g004p778x3463/ - doi:10.1007/s00468-010-0525-7

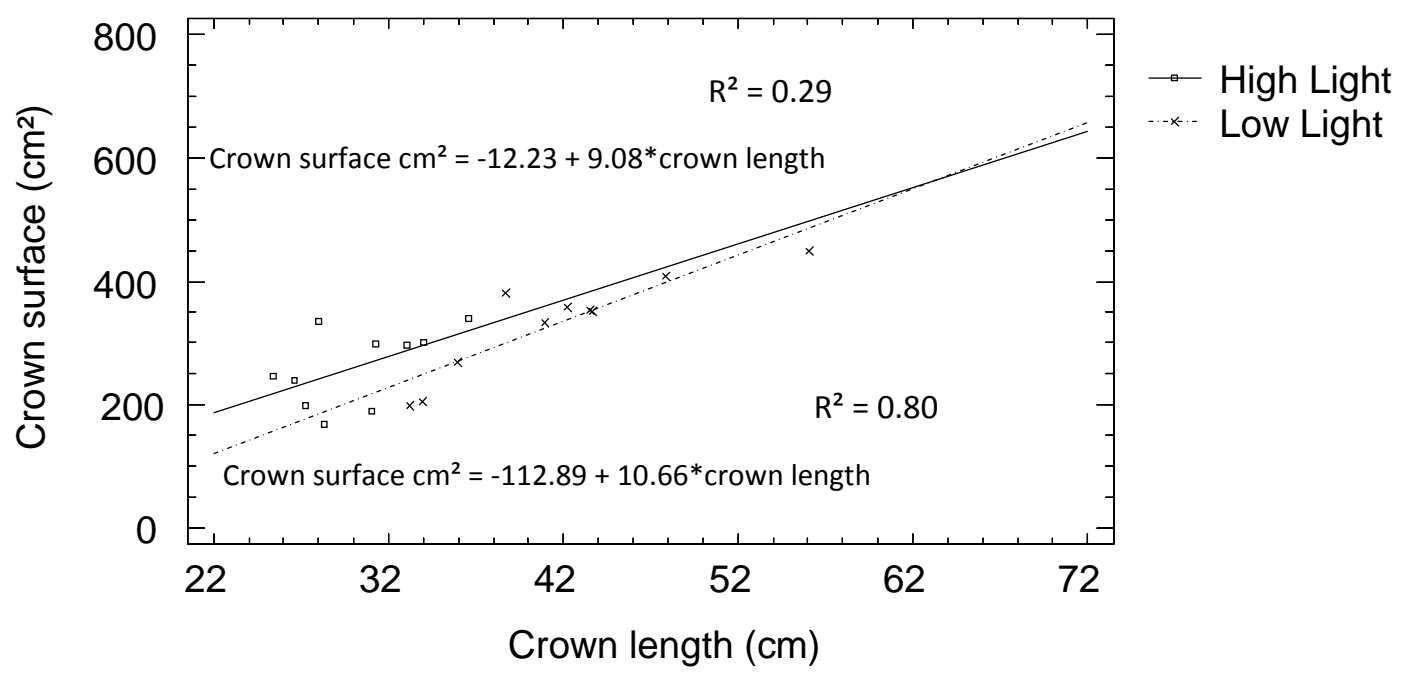

535

Fig. 3

537 

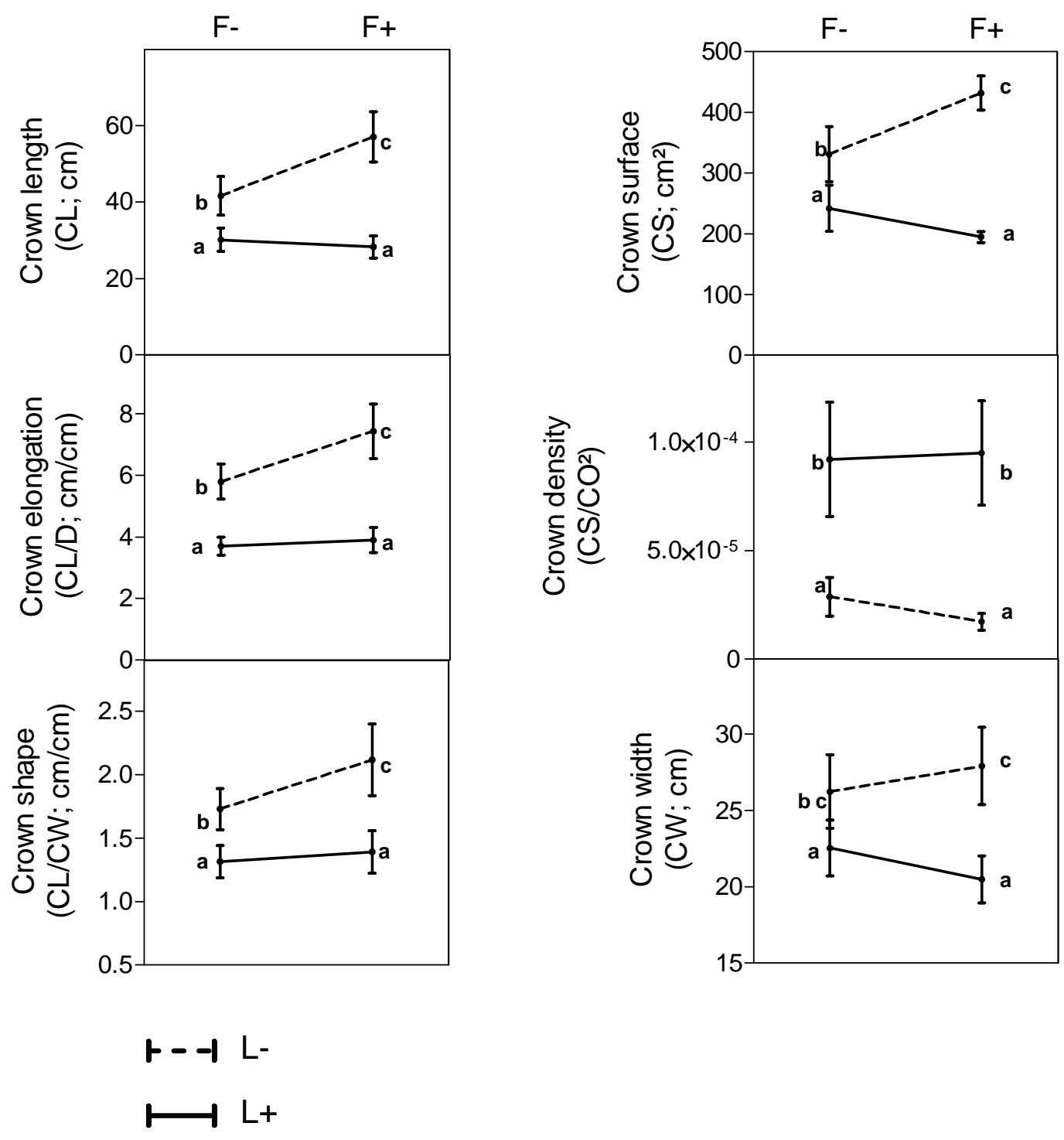

Fig. 4 

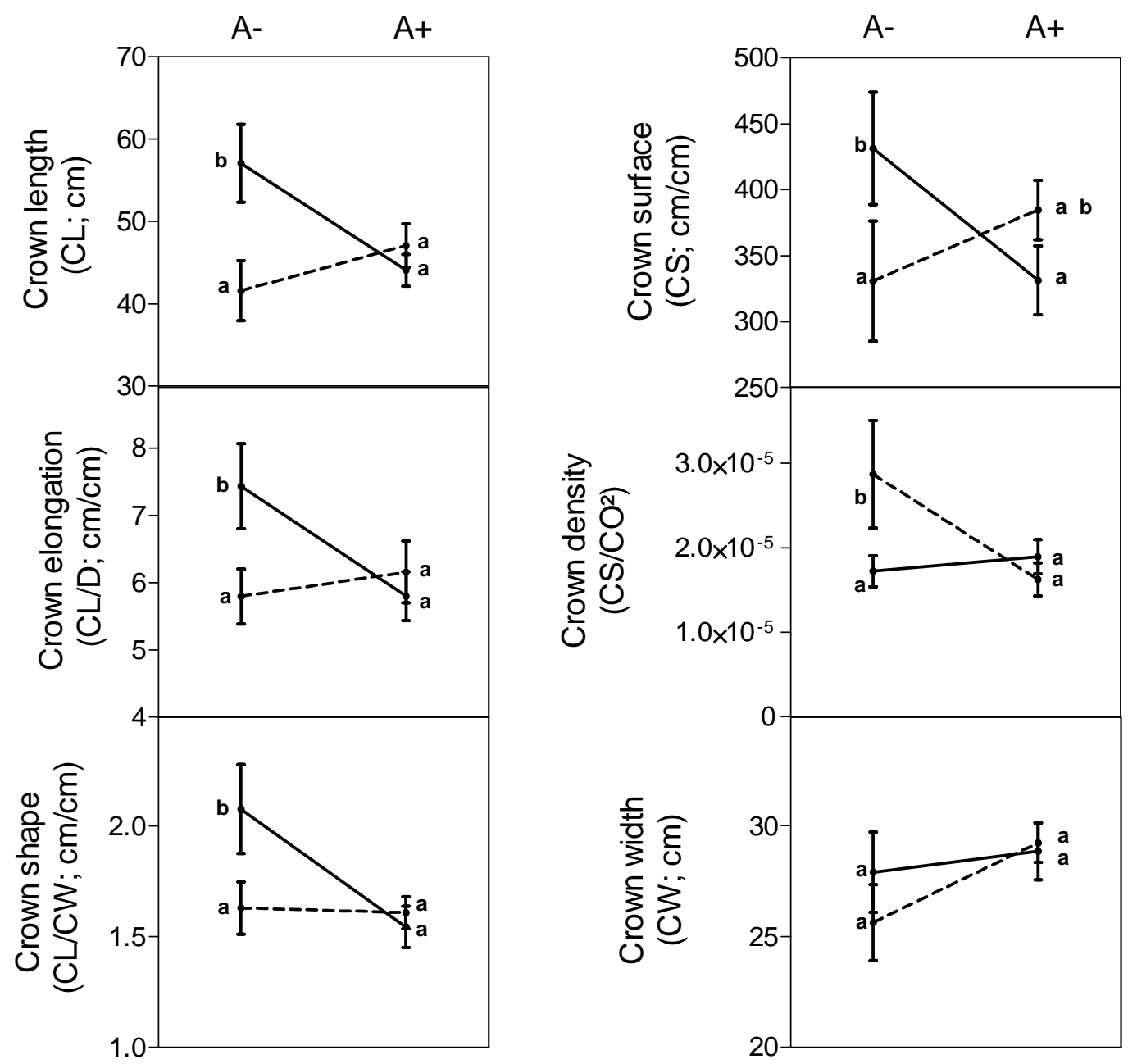

Fig. 5

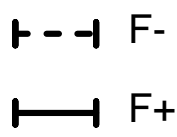

